\title{
Buyback Behaviour and the Option Funding Hypothesis
}

\author{
Rohit Sonika ${ }^{\mathrm{a}}$ and Mark B. Shackleton*†b \\ a Independent \\ ${ }^{\mathrm{b}}$ Department of Accounting and Finance. Lancaster University Management School.
}

\begin{abstract}
We study how stock option grants are funded through share repurchases under conditions of option exercisability and moneyness. Using daily repurchase disclosures by U.K. firms, we corroborate our hypothesis that driven by flexibility, firms repurchase early in an option schedule while options are out-of-money and before becoming exercisable. Our findings show that when daily stock prices are below weighted average option exercise price and when options are not immediately exercisable, firms (a) increase daily repurchase volume (value), (b) increase repurchase frequency, and (c) have lower relative repurchase prices. We further evidence this by examining the change in treasury regulation that enabled firms to hold on to repurchased shares rather than cancelling them. Our findings show a strong support for option funding motives in the post-treasury regulation period when repurchase flexibility is greater.
\end{abstract}

Keywords: Repurchase, stock options, treasury shares

JEL Classification: G30, G35, J33

${ }^{*}$ Corresponding Author: Department of Accounting and Finance. Lancaster University Management School. Lancaster. United Kingdom. LA1 4YX. E-mail: m.shackleton@lancaster.ac.uk

$\dagger$ We are grateful to Kevin Aretz, Nick Carline, James Clunie, Martin Conyon, Rüdiger Fahlenbrach, Anders Löflund, Mahendrarajah Nimalendran, Alex Taylor and seminar participants at Aalto, Minho, Brunel, FMA (Helsinki and Las Vegas), Manchester, Cardiff, Finance Forum (Madrid), Hanken and Lancaster for their useful comments and suggestions. We are also grateful to two anonymous referees for their valuable feedback. 


\section{Introduction}

Stock options play a key role in an employee's compensation contract while simultaneously shaping a firm's payout policy. In this context, share repurchases are crucial to fulfilling option exercises and avoiding stock and earnings dilution. However, the literature does not elaborate on how this link is established over the various characteristics (exercisability and moneyness) of stock options. Understanding this is significant to determining not just the cost implications of funding stock options, but also the prevalence of inherent share repurchase flexibility. The aim of our research is to fill this gap by addressing how firms use share repurchases to fund their stock option commitments.

The presence of stock options in compensation plans is often cited as a reason for the popularity of share repurchases in payout policy (Dittmar, 2000; Fenn and Liang, 2001), primarily because of the ability of share repurchases to manage the dilutive effect of stock options on existing shares outstanding. Early studies of Jolls (1998) and Weisbenner (2000) found that firms are more likely to announce repurchase programs as the levels of option grants to employees increase. While firms could issue new stock through a seasoned equity offering (SEO) (as an alternative to repurchasing existing stock from the market), it would consequently mean firms shouldering the dilutive cost of the new stock issue, while also raising the monetary and signalling cost (Eckbo et al., 2007). Repurchase, on the other hand, is anti-dilutive to earnings (Bens et al. 2003), and its non-commital feature enables firms to manage how they repurchase shares by varying transaction frequency, volume and/or value. These detailed measures of how a firm repurchases its shares allow an assessment of the role of payout in option funding under changing conditions of option exercisability and moneyness. Hence, we considered repurchase flexibility as the ability of a firm to dynamically alter its behaviour, measured through repurchase frequency, volume and value. This allows us to broaden the option funding hypothesis of Fenn and Liang (2001) and Kahle (2002) who demonstrate the influence of aggregate levels of managerial stock options on aggregate number of shares repurchased by a firm.

This broader assessment of the option funding hypothesis using detailed measures of repurchase flexibility has previously been constrained either by a lack of granular repurchase data, or considerations of repurchase programmes only. Fine details associated with repurchase implementation and option vesting characteristics are lost in aggregation, thus mak-

ing it hard to establish repurchase implementation behaviour around specific option exercise dates. These limits are visible in research by Ben-Rephael et al. (2014) and Dittmar and Field (2015) who use quarterly disclosures of monthly repurchases but lack detail on frequency and repurchase size. Additionally, merely announcing repurchase programmes does not guarantee implementation of repurchases, which consequently also fails to guarantee option funding unless implemented. Our study overcomes these data concerns by hand-collecting a sample of daily repurchase transactions by U.K. firms from 1998 to 2010. For this sample, we aggre- 
gate director-level information on exercisability and moneyness of stock option plans so as to precisely determine the significance of option funding in share repurchases.

A second issue we address in our study concerns the recognition of cost in funding option grants. Kahle (2002) and Fenn and Liang (2001) established the link between option exercisability and repurchase program announcements, while implying that firms announce repurchase programmes when options are most likely to be exercised and are in-the-money. This view of the option funding hypothesis implies that options are funded at prices close to those at which they are likely to be exercised. Funding options while they are near exercisability not only limits the underlying repurchase flexibility as they become more predictable, but also raises the cost to shareholders (i.e., the difference between repurchase and option strike price). This is in contrast to ample evidence in the literature showing that firms time their repurchases when the implied repurchase cost is lower (Dittmar and Field, 2015; Cook et al., 2004 Brockman and Chung, 2001). Using various repurchase simulation strategies, our study attempts to resolve these differences by using granular proxies of repurchase flexibility (frequency, volume and value) to assess how they are altered under different conditions of option exercisability and moneyness. We hypothesise that firms retain more opportunities to repurchase shares while options remain unexercisable which consequently allows for greater timing opportunities at prices below option strike price, ultimately lowering the cost of funding underlying grants. This argument enables us to test whether repurchase volume, value and frequency are higher while stock options are unexercisable and out-of-the-money.

We support this view of the option funding hypothesis by examining repurchase behaviour under option exercisability and moneyness conditions around a change in regulation that enabled firms to hold repurchased shares as treasury stock, a practice widely believed to provide capital cost savings. In the U.K., all repurchased shares had to be cancelled prior to 2003 but the introduction of a new regulation enabled firms to hold repurchased shares as treasury stock. Hence, if the cost savings are realisable, we predict that such savings would be more prominent in the post-regulation era as opposed to the pre-regulation period, when repurchases were predominantly undertaken when options became exercisable and inthe-money.

Our findings demonstrate an economic and statistically significant change in repurchase volume (value) associated with proportional increases in option holdings, conditional on exercisability and moneyness. We find daily repurchase volume (value) increase by 78 (214) basis points for a percent increase in options that were not exercisable and out-of-the-money. The corresponding economic magnitude for changes in options when they were exercisable and/or in-the-money revealed far smaller changes in repurchase behaviour. Observing repurchase frequency revealed qualitatively similar results, demonstrating a higher repurchase incidence rate for a percent increase in options that were not exercisable and were not in-the-money, relative to when they were exercisable and/or in-the-money. 
The change in treasury regulation was also seen to significantly impact how firms repurchase shares in the open-market. With the adoption of new regulation enabling firms to hold repurchased shares as treasury, our findings show that firms increased the volume (value) of repurchases in the new regulatory period as the levels of stock options that were not exercisable and not in-the-money increased. Similar pattern were observed for the frequency of repurchases at weekly or monthly aggregations. Conversely, we observe firms reducing their repurchase volume (value) and frequency in the new regulation period if stock options were exercisable and out-of-the-money, thus highlighting the impact of the regulatory change on repurchase flexibility and, consequentially, on option funding.

To further illustrate the role of repurchase flexibility in mitigating funding costs of stock option grants, we adopt a bootstrap method to assess different repurchase implementation behaviours and compare their costs against actuals to determine if firms realise tangible flexibility benefits. Our findings show that in the pre-regulatory change period when firms are unable to hold repurchased shares in treasury, actual repurchase prices (relative to simulated) were higher, yielding significantly higher costs. This is not surprising since most pre-regulatory period repurchases are concentrated around option exercisability, leading to repurchase prices close to option exercise prices. This is however not the case in the post-regulatory period as simulated prices are mostly similar or worse than actual repurchase prices, thus indicating a firm's ability to exercise its flexibility in share repurchases. These results largely pertain whilst holding constant the exercisability and moneyness conditions of stock options.

Our analysis provides a comprehensive illustration of the option funding hypothesis, driven by the flexibility inherent in share repurchases. We extend the existing research of Weisbenner (2000), Fenn and Liang (2001), Kahle (2002) and Bens et al. (2003) by incorporating extensive details of exercisability and moneyness of stock options. Our research also contributes to the understanding of repurchase flexibility by examining the role of treasury shares. This analysis and its further implications to shareholders greatly benefit from the data granularity provided by daily repurchase disclosure in the U.K.. Finally, our study also adds to the growing evidence on the contributions of buyback implementations on firm motivations. Recent studies of Ben-Rephael et al. (2014) and Dittmar and Field (2015) make use of monthly buyback disclosures to infer their role in market timing. Utilising daily repurchase data and framing these within the confines of option funding make for a more finely defined and more accurate evaluation of anti-dilutive repurchase programmes.

The remainder of the paper is organised as follows: the next section discusses the research motivation and the hypotheses tested; Section 3 introduces the sample data, distribution of daily repurchases and preliminary statistics on the data used in this study; Section 4 presents the empirical results and their implications; and Section 5 concludes. 


\section{Motivation and hypotheses}

Share repurchases have driven the shift in corporate payout policy since the 1990s, becoming more prominent than dividend payments (Skinner, 2008). Various theories, signalling (Vermaelen, 1981) and undervaluation (Ikenberry et al., 1995) among others, have motivated attempts to understand the importance of repurchases in corporate payout. However, empirical evaluations of these motivations have only utilised firms' intention-to-repurchase through announcements. The popularity of share repurchases is attributable to the flexibility with which firms engage in the market to buyback shares, enabling them to announce their intention to repurchase shares without any obligation. Flexibility in buybacks enables firms to address broad motives over the long-term (Dittmar, 2000). Hence, using announcements of intentions to repurchase has limited scope in establishing the importance of flexibility in buybacks.

Emerging evidence that utilises more detailed information on actual share buybacks has only partly resolved this difficulty. Using daily buyback data from France and Hong Kong, Ginglinger and Hamon (2007) and Brockman and Chung (2001) studied the impact on liquidity and market timing. A recent study by Ben-Rephael et al. (2014) took advantage of the newly available information from the U.S. to study the implications of repurchase actions at a monthly level[ 1 Using similar monthly-level data, Dittmar and Field 2015) suggest a difference in buyback behaviour that yields significant abnormal returns for infrequent repurchasers. We add to this growing body of literature by using daily repurchase transactions to examine funding of stock options, which various studies suggest as the primary reason for the growth in share buybacks.

Early work by Stephens and Weisbach (1998) acknowledges that by repurchasing shares and holding them as treasury, firms are able to meet future option exercises by employees without increasing the capital cost of funding them. These capital cost savings are realised relative to the alternative where repurchased shares are first cancelled, followed by a new equity issue through a seasoned equity offering (SEO) ${ }^{2}$ This view is further emphasised as the optionfunding hypothesis by Kahle (2002) and Fenn and Liang (2001), who broadly illustrated that the increasing importance of stock options in the employee compensation plans are directly related to the role of repurchases in reducing costs associated with stock dilution. As a result, the ability of firms to not only manage their repurchase activity (when and by how much) but also to hold on to repurchased shares as treasury plays a key role in managing option funding

\footnotetext{
${ }^{1}$ Exchange Act Rule 10b-18, which came in to effect on March 15, 2004, "provides issuers with a "safe harbor" from liability for manipulation when they repurchase their common stock in the market".

${ }^{2}$ Conducting the SEO prior to a share repurchase would visibly dilute the holdings of existing shareholders with no guarantee a repurchase would subsequently occur. Additionally, due to the multiplicity of option plans per executive with separated exercise dates, the likelihood of firms conducting an SEO every time an option plan is exercised is low due to their costly (financial and signalling) nature.
} 
costs prior to any new issue considerations.

While the traditional view of option funding emphasises capital cost savings, these are variable in nature, dependent on how firms conduct their repurchase activity. Firms could effectively repurchase shares when options are exercised, thus avoiding the need for an equity issue. This had widely been the practice in the U.K. until 2003 when all repurchased shares had to be cancelled or granted to executives and no repurchased shares could be held in treasury. In this setting, repurchase activity was highly concentrated and the timing, frequency and size of repurchases is predictable, thus constraining the flexibility in repurchase payout. Additionally, the market learns to anticipate repurchase activity around option exercises, thus leading not only to a higher market price for repurchased shares, but also repurchase price near (or over) option exercise prices. This results in higher variable option funding costs due to the inability of a firm to repurchase shares unconstrained by option exercise conditions. Alternatively, in a typical vesting period of around three years of option unexercisability, firms have ample time opportunity to repurchase shares and retain ability to adjust volume and value (size) of repurchased shares unconditionally $\left.\right|^{3}$ Hence, if options are in-the-money, firms have a cost incentive to wait for better repurchasing opportunities, while when options are out-of-the-money, firms have a cost incentive to repurchase if they expect options to become in-the-money. We test this expanded view of option funding as our central hypothesis, which we declare in alternative form as follows:

H1: Firms are likely to repurchase more (in terms of size and frequency) before options become exercisable and while they are still out-of-the-money, relative to when options become exercisable (either in- or out-of-the-money).

The hypothesis above provides a finer view of the option funding hypothesis of Kahle (2002). It also complements the dilution arguments of Galai and Schneller (1978) and Eberhart (2005), who show dilution cost from options to be approximately linear with the level of grants, thus making firms more sensitive to the size of repurchase programs. Additionally, it mimics the intuition of Babenko (2009), who suggests that the likelihood of announcing a program is higher for firms that have large quantities of unexercisable options. Our approach differs in assessing the executions of repurchases rather than the announcements of programs.

Our central hypothesis overall assumes that firms want to hold on their repurchased shares as treasury which enables repurchase flexibility to fund stock options. To more concretely test this hypothesis, we utilise a change in U.K.'s regulation, which emphasised the benefits of holding repurchased shares as treasury instead of cancelling them. As mentioned, prior to 2003, all repurchased shares had to be cancelled, meaning firms had to repurchase shares

\footnotetext{
${ }^{3}$ This is time-constrained by option exercise date, meaning as options get closer to exercise, the flexibility inherent in repurchase to mitigate option funding cost if reduced.
} 
close to option exercise to mitigate capital cost from new issues. This however contributed to greater variable funding cost since repurchase prices clustered close to prices when option were exercised. As a result, our hypothesis $H 1$ would be unlikely to hold in the period prior to 2003, which we term as pre-treasury period. After the treasury regulation adoption, firms are able to hold their repurchased shares and use them to mitigate dilution arising out of option exercise. Hence, firms would be better positioned to make use of the flexibility in repurchases more in line with $H 1$ hypothesis, resulting in greater (less) repurchase size and frequency after (before) the new regulation, for options that were unexercisable and out-of-the-money. Thus, a firm's repurchase activity would shift from the exercisable to unexercisable states of option grants. Hence, we propose extending the first hypothesis as follows:

H2: Firms are likely to repurchase more (in size and frequency) before options become exercisable and while they are out-of-the-money, relative to when options become exercisable (in- or out-of-the-money), subsequent to the 2003 change in treasury regulation than they were prior to this change in regulation.

The hypotheses $H 1$ and $H_{2} 2$ indicate that firms are able to better monitor their repurchase size with increased flexibility, especially after the adoption of treasury regulation. Similarly, increased repurchase flexibility post-regulation change would allow a firm to obtain better relative repurchase prices, as opposed to before regulation change and in states of options being exercisable and in-the-money. While the prices obtained when options become exercisable and/or in-the-money could help anti-dilutive options when they are exercised, the expanded flexibility to repurchase is likely to yield more competitive relative repurchase prices while options are still unexercisable and out-of-the-money. Hence, in line with prior hypotheses, we propose the following hypothesis to test if there is tangible value gained by increased repurchase flexibility:

H3: Average relative repurchase prices obtained before options become exercisable and while they are out-of-the-money are likely to be lower, relative to when options become exercisable (in- or out-of-the-money), subsequent to the change in treasury regulation than they were prior to this change in regulation.

The hypotheses highlighted above help clarify if share repurchase behaviour enables funding of stock option grants under the complex dynamics of option exercisability and moneyness. Additionally, we were also able to contextualise the same relationship in the presence of a regulation change as to how firms account for repurchased shares and the associated tangible costs. Section 3 below describe our data and Section 4 reports our findings. 


\section{Data}

\subsection{Sample construction}

Similar to Rees (1996), we utilise the U.K. regulatory framework, which requires firms to disclose their repurchase volumes and prices within one trading day of the transaction date $4^{4}$ As data on daily buyback implementations are not readily available from secondary sources, we gathered a list of firms that sought buyback authorities from the Securities Data Company (SDC) database. We isolated open-market programs from tender-offers or Dutch auctions to identify 196 firms with repurchase authorities and, using the Perfect Information (PI) database, verified 2,762 firm-years and 10,623 daily repurchase transactions during the period between 1990 through 2010. Since implementation of an open-market program is non-obligatory, daily repurchase transactions pertained to only 119 firms in the sample.

In the context of option funding through repurchases, we required that the firm have provided exercisable dates of various vanilla and long-term incentive option plans of their executives. Information on particular option plans are difficult to track down through annual reports, especially for all firm executives. Hence, we utilised the BoardEx database to obtain detailed information on option exercisable dates for each firm, by director-option plan. De Cesari and Ozkan (2015) used the BoardEx in a similar manner, but our approach differs in how we aggregated information on option exercisable dates in conjunction with daily repurchase data to obtain an accurate picture of repurchase behaviour around option exercisability. Hence, for all directors, we aggregated the data by all option plans that were available for all years when a plan was active or had options outstanding 5 Collating all available option plans for each director to determine unique exercisable dates helped us to clarify the number of options outstanding at different exercisable stages. We then merged these data with our hand-collected repurchase data. A constraint in the BoardEx data was that their coverage began in 1999. Thus, when this sample's data were merged with our repurchase dataset, information prior to this period was lost. Hence, the merged, final dataset represented 9,129 firm-repurchase days over the final sample period covering 1999 through 2010. These buybacks corresponded to 80 firms with 39 additional firms in our sample obtaining repurchase authorities but not implementing them during the sample period. Table 1 provides a description of how this sample was compiled.

\section{[TABLE 1 GOES HERE]}

\footnotetext{
${ }^{4}$ London Stock Exchange Listing Rule 12.4.6 states that "any purchase of a listed company's own equity shares by or on behalf of the company or any other member of its group must be notified to a Regulatory Information Service (RIS) as soon as possible, and in any event by no later than 7:30 a.m. on the business day following the calendar day on which the purchase occurred."

${ }^{5}$ Thus, if an option plan fell out of the dataset without expiring, we assumed the plan had either been exercised or was cancelled.
} 


\subsection{Daily share repurchase distribution}

Table 2 below illustrates the distribution of the 9,129 daily repurchases that occured between 1999 and 2010 for our sample firms.

\section{[TABLE 2 GOES HERE]}

To understand how repurchases are implemented in the U.K., we illustrate the aggregate and yearly distributions of repurchase volume, frequency, and cost, at both transaction and firm-level. We observe that mean (median) volume of repurchases peaked at either ends of the sample period. An average firm in our sample repurchased approximately 0.10 percent of its total shares outstanding per transaction, which translated to 1.48 million shares ${ }^{6}$ Overall, if a firm repurchased, it did so on average 12.3 percent of its total shares outstanding through the open-market over our sample period.

We discovered that the frequency of repurchase transactions during the sample period was greater when mean (median) volumes were low, suggesting that the firms, while repurchasing fewer shares, were doing so with less intensity but with activity spread over long periods. In contrast to Dittmar and Field (2015), who provide frequency statistics based on a firm's monthly repurchase activities, our sample firms that transacted did so at an average of 114 times during our sample period 7 The cost statistic further shows this frequency of repurchase transaction, where the mean (median) cost to firm or per transaction was noticeably lower from 2001 to 2006. Our sample firms spent approximately 0.10 percent of their market value per transaction (similar to number of shares), resulting in an average outlay of 5.1 million (GBP) on a repurchase day. Overall, repurchasing firms bought back approximately 11.9 percent of their relative market value over our entire sample period 8

\subsection{Descriptive statistics}

Table 3 below details the summary means, medians and standard deviations of the variables across the whole sample and sub-samples of repurchasing firms of this study.

\section{[TABLE 3 GOES HERE]}

Univariate tests suggested that differences between repurchasing and non-repurchasing firms were significantly different on all measures used in the study. We found repurchasing

\footnotetext{
${ }^{6}$ Average number of shares outstanding for our sample firms was 1.48 billion. Similarly, average market value of sample firms was GBP 5.1 billion.

${ }^{7}$ Due to the unbalanced nature of our data, not all firms are active during the entire sample period.

${ }^{8}$ The measures of volume, frequency and cost do not account for closed periods in the U.K.. London Stock Exchange Listing Rules 12.2, since been superseded by the EU Market Abuse Regulation (EU) No 596/2014 sets out limits on trading by companies and managers during price-sensitive periods.
} 
firms to be larger (proxied by market value), but with increased investment opportunities (proxied by market-to-book ratio). These statistics are partially in line with agency theory expectations, which predict that larger firms choose to repurchase shares as they transition to a mature stage (Grullon and Michaely, 2004). Relative to non-repurchasing firms, repurchasing firms were found to be highly leveraged and to possess lower amounts of cash, while also exhibiting lower volatility, lower spread, and past stock returns. This implies that potential costs from transacting in the market might be lower for firms repurchasing shares.

All these variables entered as controls in our study, with our main variables of interest being aggregate and segregated levels of director stock options. Our measure of stock options include both vanilla and long-term incentive plan (LTIP) options, the latter being very prominent in the U.K. Here, sample repurchasing firms were found to have issued fewer stock options relative to non-repurchasing firms. When segregated on option exercisability and moneyness, repurchasing firms again showed significantly lower levels of both exercisable and unexercisable grants, either in- or out-of-the-money 99 Overall, the univariate statistics and test results suggest that repurchasing firms differ markedly on many measures used in our study 10 We now discuss test as to whether these differences hold up in a multivariate setting using dynamic and count models. These results are discussed in the next section.

\section{Empirical findings}

\subsection{Repurchase size}

We evaluate the option funding motivation by first examining the influence of increasing levels of option grants and their exercisability and moneyness conditions on levels of daily repurchases. The flexibility in repurchase is first examined by the size (volume and value) of daily repurchase transactions, and a firm's behaviour to manage it based on underlying levels and conditions (exercisability and moneyness) of stock options. As we motivated earlier, repurchase flexibility could result in either an increase or decrease in repurchase sizes. However, in the option funding context, we expect to observe an increasing relationship between levels of stock options and repurchase size. Where this relationship becomes most apparent in the mix of exercisability and moneyness conditions will be determined by the timing and cost benefits of repurchase flexibility in funding option grants to a firm. Hence, in line with our stated hypothesis, we examine this relationship in Table 4 below.

\footnotetext{
${ }^{9}$ Univariate tests show repurchasing firms to have fewer proportional vanilla and LTIP options outstanding, at different levels of option exercisability and moneyness. Results are available upon request.

${ }^{10}$ We also conducted a correlation test and confirmed an absence of co-linearity between our variables. Results are also available upon request.
} 


\section{[TABLE 4 GOES HERE]}

The results presented in Table 4 above are determined using a dynamic system generalised method of moments (GMM) regression in a panel framework that included a one-day lagged value of the relevant dependent variable as an additional control. We employ this dynamic model to account for various market-level constraints on volume and price, which frequently cause a firm's repurchase action to be spread over multiple days, thus creating serial dependency in the dependent variable. With respect to instruments, to avoid proliferation, we limited the number of lags the model could employ to one 11 This method was applied to two measures of repurchase size: volume and value. We defined repurchase volume as the number of shares repurchased as a percentage of the total shares outstanding, while value as the daily outlay spent on repurchases (i.e. the number of shares repurchased multiplied by repurchase price) as a percentage of daily market value. In addition, we controlled for various firm-level fundamentals, including size, investment opportunity, leverage, cash, asset return, return volatility, bid-ask spread and dividend-payer status as indicated by a binary variable.

Consistent with the findings of Fenn and Liang (2001) and Kahle (2002), our results showed that increasing levels of aggregate stock options yielded higher repurchase size, leading firms to repurchase more shares as the levels of aggregate option grants increase to reduce dilution. Economically, we observed a 38 basis point increase in daily repurchase volume for a percent increase in aggregate stock options outstanding. Moreover, consistent with our expectations of repurchase flexibility and option funding, we observed a 78 basis point increase in repurchase volume for a one-percent increase in unexercisable, out-of-the-money option levels. Moreover, increased repurchases for increasing levels of exercisable options (both in- and out-of-themoney) were economically weaker but statistically still significant. This indicates that firms overall tend to prefer repurchasing shares while options are still unexercisable and out-of-theout-of-the-moneymoney, thus enabling more timing opportunities.

Changing the identifier to repurchase value (columns 3 and 4) yielded similar results. Quantitatively, a percent increase in aggregate options outstanding led to a 65 basis points increase in daily repurchase value, and a large proportion of this effect was again driven by unexercisable, out-of-the-money options. This resulted in a 2.15 percent increase in daily repurchase value per percent increase in the same option group, further indicating a desire for firms to repurchase when they are not time constrained by option exercise. Thus, options that are exercisable (in or out-of-the-money) and in-the-money unexercisable options yield much lower economic effects on daily repurchase behaviour.

All control variables we specified contributed significantly to the determination of daily transaction size. A firm's repurchase activity increased relative to firm size, leverage, return

\footnotetext{
${ }^{11}$ These models were estimated using the xtdpdsys command in Stata, with the twostep option and a single lagged dependent variable as instrument (excluded from results, for brevity). The model was found to be robust to inclusion of more lags as instruments.
} 
on assets and volatility, all of which reinforce the flexibility motivation behind repurchases. Economically, the effect on repurchase behaviour is stronger than that identified with options, showing greater changes in repurchase frequency with proportional increases in firm leverage, return on assets and return volatility. While they do indicate the multi-dimensional nature of motives behind repurchases, these variables act as controls while retaining our focus on stock options. The firms in the sample also reduced their volume when spreads widened or when lagged returns increased, showing a tendency not to repurchase as costs increase. Our cash variable captured the permanent component of firm cash resource, thus confirming the arguments of Stephens and Weisbach (1998).

To further support the anti-dilutive, option funding argument, we re-examined the specifications presented in Table 4 by including dummy and continuous variables of treasury shares that distinguished between the U.K.'s different regulatory periods. The dummy variable Treasury defined when firms were able to hold repurchased shares as treasury, and so minimise their cost of funding stock options (Stephens and Weisbach, 1998). We interacted this variable with our primary variables of interest, and Table 5 below displays the results of this analysis.

\section{[TABLE 5 GOES HERE]}

In the specification of Table 5, we interact the Treasury dummy variable with both aggregate and segregated measures of option holdings, while also keeping the main effects of the latter variables. In the specification, this results in the main effect as the pre-treasury effect of stock options on repurchase size, with the interaction term indicating the difference between treasury periods. Our findings here are qualitatively similar to those displayed in Table 4, although the inclusion of the Treasury dummy increases the roles option exercisability and moneyness play in daily repurchase implementation.

We find the pre-treasury effect of aggregate options to significantly influence both repurchase volume (35 bps) and value (62 bps), but the economic and statistical significance remains unchanged in the post-treasury period, as highlighted by the interaction term. This interpretation is altered when we segregate the option grants variable (columns 2 and 4). We found exercisable options (both in- and out-of-the-money) to be a significant driver of repurchase activity prior to the adoption of the treasury regulation as indicated by the main, uninteracted variables. However, in the post-treasury period, both moneyness levels of exercisable options showed significant economic decline in their relationship to repurchase size. Either moneyness segregations of exercisable options indicated an under 20 bps change (difference in main and interaction coefficients) in repurchase volume and value. Conversely, the economic importance of unexercisable, out-of-the-money options increased repurchase volume (value) by 1.05 (2.43) percent points from pre-treasury levels of approximately -20 bps for a percent increase in the option levels. This finding further shows that when given the flexibility to repurchase in order

to fund option grants, firms will prefer to shift their repurchase behaviour while options are 
still unexercisable and out-of-the-money. This is in line with our expectations regarding the increasing significance of unexercisable grants, which appear to increase repurchase flexibility for firms wishing to fund their option grants. All control variables continue to show similar economic and statistical significance as observed in Table 4.

Overall, our results indicate that the relationship between stock options and repurchase size is sensitive to the segregation of stock options based on exercisability and moneyness conditions, as well as to the treasury period. This lends support for our hypothesis that firms do repurchase more shares and invest proportionally more as payout flexibility is enhanced before options become exercisable and when they are out-of-the-money.

\subsection{Repurchase frequency}

The second metric that we use to assess the significance of repurchase flexibility in funding option grants is through the periodic counting of repurchase transactions. Recent study by Dittmar and Field (2015) found firms exercising their flexibility by repurchasing on fewer occasions for better market timing. However, as we highlighted earlier, such levels of aggregation disguise the true repurchase intensity as they do not reveal if repurchase transactions are undertaken in just a single trading day or every trading day within a group. With our daily repurchase data, we are better placed to more accurately determine if flexibility drives firms to repurchase more or less often to fund option grants.

In the option funding context, firms have the possibility to repurchase either while stock options are still unexercisable, or wait until options become exercisable. A problem with waiting for exercisability is that repurchases would be so highly concentrated markets could anticipate such a behaviour. This would also result in repurchase prices being pushed higher, resulting in higher option funding costs. Alternatively, repurchasing while options are still unexercisable does utilise cash early, but provides firms with ample repurchasing time flexibility. Hence, we should expect that as the anti-dilution needs of a firm increases with increasing levels of stock options, a firm can benefit by timing share repurchases before options become exercisable, and are out-of-the-money. Repurchasing after options become exercisable constrains flexibility as a firm is driven more by the exercise needs of the option holder and less by the flexibility apparent in repurchase programs. We illustrate our findings in Table 6 below.

\section{[TABLE 6 GOES HERE]}

Observing the univariate summary statistics on repurchase frequency (Table 2), we notice that the repurchase tendencies of firms are widely dispersed, rendering a standard count model biased in estimated standard errors. The negative binomial model accounts for this overdispersion in count by estimating the standard errors independently of the means ${ }^{12}$ In this

\footnotetext{
${ }^{12}$ Due to the unbalanced nature of our data, not all firms are active during the entirety of our sample
} 
regard, we employed this model in both monthly and weekly groupings of repurchase frequency to make use of our dataset's granularity. For both monthly and weekly frequency grouping, we collate a firm's total count of repurchase transactions, with each time grouping taking a value of zero if no repurchase occurred in that time period. We show results for both time groups for aggregated and segregated option holdings variables.

The results shown in Table 6 suggest that firms on average increase their payout frequency by approximately 7 percent in a month for each percent increase in aggregate options outstanding. When segregated, this relationship is driven largely by unexercisable, out-of-the-money grants, indicating a 26 percent increase in monthly frequency. This amounts to nearly two additional repurchase days in a month for a percent increase in unexercisable, out-of-the-money grants 13 Results based on weekly aggregation of repurchase frequencies (columns 3 and 4) show economically and statistically stronger associations. While repurchase frequency is still increasing in aggregate option holdings (14 percent), this is again driven largely by the level of unexercisable, out-of-the-money grants. However, qualitatively similar results are also observed for exercisable options that are in-the-money, pointing to an additional repurchase day in a week for each percentage increase in the stated underlying options. We investigate this result further by assessing the role of the treasury regulation in the option funding hypothesis.

We also found increasing firm size, increasing cash holdings but decreasing investment opportunities led to increased frequency of repurchases. This is in line with how firms spread their payout needs as they transition to a mature state (Grullon et al., 2002). Frequency is sensitive to volatility, spread and lagged returns, indicating the desire by firms to repurchase more often as the costs associated with such repurchases decline. The economic effect is consistent across weekly and monthly models and much more strongly for lagged returns which also indicates an aversion to repurchasing more frequently while market prices are higher (and vice versa). Finally, we found an economically marginal link between frequency and dividend payout, indicating a desire amongst dividend paying firms to repurchase more frequently.

Our findings show a more robust understanding of gains in repurchase frequency using weekly data relative to monthly data aggregations, as a result of increased observations and less information aggregation. We next tested the validity of these results by interacting the Treasury dummy variable so as to determine the significance of flexibility in option funding. If firms valued flexibility in repurchasing shares more broadly (as opposed to only repurchasing while options are exercisable and cancelling repurchased shares), we should witness a shift in repurchase behaviour towards increased frequency while options are unexercisable in the

period. As a result, the over-dispersion in the count explanatory variable makes the standard Poisson model inappropriate for a robust estimation. Hence, following Cameron and Trivedi (2008), we employ the negative binomial model that allows us to relax the conditional variance, mean conditions while also accounting for the dispersion through an additional parameter.

${ }^{13}$ Sample firms on average repurchase 114 times over the sample life, but 8 times during a repurchase month and 3 times during a repurchase week. 
post-treasury period. These results are tested in Table 7 below.

\section{[TABLE 7 GOES HERE]}

Changes in repurchase behaviour between regulation periods are qualitatively similar to the results displayed in Table 5, as are the implications for funding option grants. In the case of aggregate stock options (columns 1 and 3), the monthly count models showed relatively weaker economic and statistical power. At the weekly level, the incidence of repurchases increased by 26 percent in the pre-treasury period for each percent increase in aggregate options (main effect). This association is weakened in the post-treasury period as we see a decline of about 12 percent (interaction coefficient of 0.8852 ) in weekly repurchases relative to the pre-treasury period for a percent increase in aggregate option levels. This indicates that while increases in aggregate options still yield higher repurchase frequencies, this rate is lower in the post-treasury period relative to that in the pre-treasury period. Findings for the segregated variables are much more informative (columns 2 and 4), as we observe differing patterns for both exercisability and moneyness conditions of stock options. While firms in the pre-treasury period exhibited significantly lower repurchase frequencies before options were exercisable (63 percent lower frequency than weekly average, per percent increase in unexercisable, out-of-the-money options), this effect is reversed in the post-treasury period by a factor of 3.76 relative to pre-treasury levels, yielding positive increases in weekly repurchase frequency for a percent increase in unexercisable, out-of-the-money options. Similar results are observed at the monthly level.

Alternatively, pre-treasury levels of exercisable, out-of-the-money options yield higher repurchase frequency (than monthly or weekly averages) but this effect too is reversed in the post-treasury period. At the extreme, we find the weekly frequency of exercisable, out-of-themoney options to be nearly 50 percent lower than pre-treasury levels. This implies that firms were repurchasing fewer times in the post-treasury period for a percent increase in exercisable, out-of-the-money options. Interestingly, this behaviour was only concentrated in the out-ofthe-money portions of stock options as we did not observe any change in repurchase behaviour between regulatory periods for in-the-money options.

Overall, our findings here suggest a significant relation between levels of aggregated and segregated options holdings and the frequency with which a firm repurchases. Firms were more likely to increase their repurchase counts with increasing levels of unexercisable grants that were not in-the-money, predominantly in the post-treasury regulation period. This is in contrast to the observations for exercisable, out-of-the-money grants, where the frequency was lower for increasing levels of the grants, especially in the post-treasury period. These findings suggest that firms indeed saw the ability to hold repurchased shares as an advantage in funding option grants, which was fulfilled through repurchasing early and while options were out-of-themoney. Whether this repurchase behaviour resulted in better market timing opportunities and 
lower option funding cost remains unanswered. We address this issue next, while considering conditions of option exercisability, moneyness and treasury regulation periods.

\subsection{Bootstrapped repurchase costs}

Our findings above illustrate that in the context of stock options pre-treasury regulation repurchases were concentrated around options that were exercisable and out-of-the-money but the introduction of treasury regulation shifted that behaviour towards unexercisable, out-of-themoney options. The change in repurchase behaviour was rational since repurchasing before option become exercisable provide more time flexibility in the anti-dilution objective. These shifts in behaviour would also be justified if the implied cost of repurchasing shares were to be reduced in the post-treasury regulation period. This is formally declared under our third hypothesis (H3), wherein using granular repurchase implementation data, we look to determine if repurchase prices were better than alternative market prices in the post-regulation period under various exercisability and moneyness conditions of stock options.

We adopt the bootstrap scenarios suggested by Brockman and Chung (2001) and Cook et al. (2004). More specifically, we compared actual daily weighted average repurchase price to alternative bootstrapped prices based on various implementation scenarios. The scenarios we adopt for the test are minimum volume, average volume and maximum volume where the minimum, mean and maximum daily repurchase volume are separately bootstrapped over the sample period to generate a randomised sample in each scenario. More concretely, we first aggregated total shares repurchased by each firm in our sample, during the sample period and then determined, for each alternative scenario, the number of trading days needed for the firm to fulfil its actual repurchase implementation size. This is done to ensure that the aggregate repurchase volume remains the same across all scenarios, relative to the actual repurchase size, while the price is randomly assigned based on number of trading days under each setting. Hence, under each instance and scenario, the volume remained constant but the number of bootstrapped repurchase days that a firm could have repurchased (but had not) differed between scenarios. Each bootstrap scenario was then repeated 100 times over non-repurchase days in our sample period to enable the determination of mean daily prices. For each scenario, the randomly determined prices were then scaled by the actual weighted mean daily repurchase price to establish if actual repurchase prices were better (i.e. a ratio greater than 1) or worse (ratio lower than 1).

We illustrate how the bootstrap method is operationalised with an example. A sample company repurchased ten times during its sample life of 10 years with aggregate repurchase volume of 500,000 shares. Over the ten repurchase transactions, the smallest repurchase (minimum) transaction size was 10,000 shares, while the largest repurchase (maximum) was 100,000. The mean repurchase size was 50,000. In the bootstrap setting, for the minimum 
(maximum) size scenario, a repurchase volume of 10,000 $(100,000)$ was randomly drawn 50

(5) times per run from the non-repurchase days so that the aggregate volume equated to the actual repurchase volume. This randomisation is repeated 100 times to determine aggregate bootstrapped prices as well as means across different states of stock option grants. These means are then, individually, scaled by the actual weighted mean repurchase price (aggregate and segregated) to establish a market timing metric. If the ratio is greater than 1 , this would imply that actual repurchase prices obtained were lower than bootstrapped ones, thus resulting in better market timing, and vice versa.

Since the scenarios randomly assigned repurchase days, we were also able to test for a firm's market timing ability across treasury regulation states. In the treasury setting, we would expect firms to exhibit better timing ability post-regulation change due to increased flexibility from the ability to hold on to repurchased shares as treasury. Similarly, we should expect to observe firms obtaining better market prices when options were not exercisable and were out-of-the-money as they enable greatest repurchase flexibility. Our findings are shown in Table 8 below.

\section{[TABLE 8 GOES HERE]}

Panel A in Table 8 above shows aggregate values across all alternative settings. As can be seen, firms on average possessed timing ability in the mean (ratio greater than 1) but not in the medians (except in closing price strategy). Barring average volume, bootstrapped medians are only marginally lower (6 to 62 basis points), suggesting that firms do marginally worse with their repurchase timing. However, when we split the data between treasury periods, we consistently observe significantly better timing at the median in the post-regulation period. The range of difference in timing ability between the treasury periods is around 10 percentage points across different settings, thus illustrating that repurchases were, by and large, better aligned to option funding given the ability to hold repurchase shares in treasury. Mean bootstrapped prices do show better timing in the pre-treasury period, but the difference between mean and median suggests a highly skewed distribution.

Panels B-D examine the same bootstrapped repurchase data under different conditions of option exercisability and moneyness. Since most of our earlier findings indicate a firm's preference to repurchase while options are unexercisable and out-of-the-money (due to increased repurchase flexibility), we were primarily interested in how timing of share repurchases for affected option characteristics are altered relative to this unexercisable, out-of-the-money option state. In the findings shown in Panel B, we considered the difference in moneyness parameters, holding the unexercisable state of stock options fixed. To aid our understanding, we sought to determine if on bootstrapped repurchase days a firm had a larger proportion of out-of-themoney, unexercisable options, relative to in-the-money options. In line with our predictions that firms can enjoy more flexibility in their repurchase when options are out-of-the-money, we 
found that, on aggregate, firms do better in timing their repurchases when they possess larger proportions of out-of-the-money, unexercisable options, relative to in-the-money options. This is not conditional on a firm's implementation strategy as the aggregate mean and median were significantly higher, yielding a ratio greater than 1 . When observing segregation by treasury period and consistent with our expectations that post-treasury period would yield better timing opportunities, we find that the difference between the two ratio groups was much greater in the post-regulation period, with consistently better timing when firms held relatively larger proportions of unexercisable, out-of-the-money options. Finally, observing the significance of difference in ratios across regulation periods, we witness the effect of treasury regulation impact on all settings except for maximum volume strategy thus highlighting the importance of the regulation in a firm's ability to exercise flexibility in option funding.

In Panel $\mathrm{C}$, we hold the out-of-the-money state of stock options constant and compare between exercisable and unexercisable states of stock options across all alternative repurchase settings. Similar to Panel B, we complement our findings by splitting the comparison to groups with proportionally more unexercisable options (Ratio $>1$ ) to groups with proportionally more exersiable options (Ratio $<1$ ). Holding the moneyness parameter constant, we should expect firms to have better timing ability when proportionally larger number of unexercisable options are outstanding and in the post-regulation period. However, in the out-of-the-money state, the difference between the two groups of options outstanding might be small as also witnessed in our multivariate findings. As our aggregate findings show, firms between two stock option states do not differ much at the mean across strategies, but observing the median shows firms to largely do better in timing when larger proportions of unexercisable options are outstanding. This observation is also maintained when comparing the findings across treasury periods. With means highly skewed in the pre-treasury period, large unexercisable option groups do show better market timing at the median relative to the alternative, but the overall timing is still poor (ratio of less than 1, except minimum volume scenario). The effect of treasury regulation again shows significant changes with median values consistently better across scenarios (barring maximum volume).

Finally, in Panel D, both the exercisability and moneyness parameters have been adjusted by comparing the levels of unexercisable, out-of-the-money options to those for exercisable, inthe-money options. These findings largely mimic those displayed in Panel B for the aggregate but the most visible change is observed in the comparison between treasury regulation periods. We observe better timing ability for firms having more out-of-the-money, unexercisable options across all scenarios in the post-regulation period while the difference between the two groups remain unclear in the pre-treasury period. This again highlights the significance of the treasury regulation change, especially for unexercisable, out-of-the-money option states when flexibility to repurchase is most prominent.

Overall, the bootstrapped results suggest that firms are able to capitalise on increased 
repurchase flexibility that yields better repurchase prices, especially when holding larger proportions of stock options that were not exercisable and were not in-the-money, and when such repurchases were undertaken in the post-treasury regulation period. Interestingly, we do find the maximum volume alternative has weak statistical power, suggesting that by concentrating repurchases in short bursts, prices obtained were no different across treasury periods. These findings are robust to different scenarios of repurchase implementation, although the power of the test varies between scenarios.

\section{Conclusion}

Share repurchases have become the dominant means through which firms execute their payout policy, driven primarily by the flexibility inherent in share repurchases, which enables firms to implement open-ended programmes without any commitment (Sonika et al., 2014). This flexibility has an important bearing on how, when and if firm stock options are anti-diluted. In this regard, contradictory evidence and insufficient data resources highlight a disagreement on the role of option conditions (i.e., exercisability and moneyness) on repurchase implementation. Our study sought to address these concerns by exploring the significance of stock option exercisability and moneyness conditions on actual firm repurchase behaviour.

Using a unique sample of daily repurchase transactions from the U.K., we examined the effect on daily repurchase volume, value and periodic frequency as proxies of repurchase flexibility when firms were driven to fund their outstanding stock option grants to directors. We argue that payout flexibility is constrained and predictable; if firms repurchase after option grants become exercisable and in-the-money, the option exercise needs of a firm drive payout demands. This constraint results in higher repurchase prices than would be possible otherwise.

Our findings indicate that firms are inclined to repurchase more shares and allocate greater proportional value to payout if associated grants are unexercisable and out-of-the-money. We observed a 78 (214) basis points increase in repurchase volume (value) per percent increase in outstanding unexercisable, out-of-the-money options. Correspondingly, economic significance of other option exercisable states was positive, but at least 60 percent lower. Similar results occurred when repurchase frequency was considered, with identical repurchase incidence rates for unexercisable, out-of-the-money and exercisable, in-the-money options in weekly regressions. These findings were, however, sensitive to the degree of flexibility in repurchasing shares. Using a change in regulation that enabled firms to hold repurchased shares as treasury, we found our results to be valid across regulatory periods. As we demonstrated, repurchase volume, value and frequency increased post treasury regulation for firms holding large proportions of total options as unexercisable and out-of-the-money. Similarly, we found the repurchase volume, value and frequency reduced for exercisable options. 
The argument that firms repurchase shares early in the option's vesting schedule and while they are out-of-the-money implies a role for repurchase flexibility plays in funding option grants. As a result, this flexibility should confer better (lower) repurchase prices for a firm. We tested this in a bootstrap exercise that replicated a firm's repurchase behaviour over nonrepurchase days using various implementation strategies. As our findings demonstrated, firms typically obtain repurchase prices better than simulated prices, and when they held larger proportions of unexercisable, out-of-the-money options (relative to other option states). More importantly, results appears sensitive to the treasury period as well as the states of option exercisability and moneyness. Firms were able to obtain better prices in repurchases over simulated cases in the post-regulation period and while options were unexercisable and outof-the-money. These findings were robust to comparison with alternative cases and strategies determined through simulation.

Our study is most closely related to those described in the literature addressing the relationship between share buybacks and stock options (Fenn and Liang, 2001; Kahle, 2002; Bens et al., 2003). While the state of option grants may not economically be a primary driver in determining repurchase behaviour, the dilution implication from stock options is visible, and the empirical evidence fills a gap in our understanding of how and why firms execute share repurchases. Our study also circumvents the anti-dilutive arguments of total payout (Cuny et al., 2009) by illustrating the manner in which firms undertake their daily repurchases under conditions of option exercisability and moneyness. Consequently, our study also extends the evidence surrounding the frequency of buybacks (Dittmar and Field, 2015) by using a more granular daily transaction dataset to explore the impact on repurchase continuity. Evidence on the anti-dilutive implications of buybacks supports the suggestion of Ben-Rephael et al. (2014) that firms should be required to disclose their actual repurchases more frequently than quarterly as currently required in the U.S.. This should enable a reassessment of payout motives based on actual buyback activity instead of a non-committal intention to repurchase only. 


\section{References}

Babenko, I. 2009. Share Repurchases and Pay-Performance Sensitivity of Employee Compensation Contracts. The Journal of Finance 64:117-150.

Ben-Rephael, A., J. Oded, and A. Wohl. 2014. Do Firms Buy Their Stock at Bargain Prices? Evidence from Actual Stock Repurchase Disclosures. Review of Finance 18:1299-1340.

Bens, D. A., V. Nagar, D. J. Skinner, and M. H. F. Wong. 2003. Employee stock options, EPS dilution, and stock repurchases. Journal of Accounting and Economics 36:51-90.

Brockman, P., and D. Y. Chung. 2001. Managerial timing and corporate liquidity:: evidence from actual share repurchases. Journal of Financial Economics 61:417-448.

Cameron, A. C., and P. K. Trivedi. 2008. Microeconometrics Using Stata. Stata Press.

Cook, D. O., L. Krigman, and J. C. Leach. 2004. On the Timing and Execution of Open Market Repurchases. Review of Financial Studies 17:463-498.

Cuny, C. J., G. S. Martin, and J. J. Puthenpurackal. 2009. Stock Options and Total Payout. Journal of Financial and Quantitative Analysis 44:391-410.

De Cesari, A., and N. Ozkan. 2015. Executive incentives and payout policy: Empirical evidence from Europe. Journal of Banking \& Finance 55:70-91.

Dittmar, A., and L. C. Field. 2015. Can managers time the market? Evidence using repurchase price data. Journal of Financial Economics 115:261-282.

Dittmar, A. K. 2000. Why Do Firms Repurchase Stock? The Journal of Business 73:331-355.

Eberhart, A. C. 2005. Employee stock options as warrants. Journal of Banking 6 F Finance 29:2409-2433.

Eckbo, B. E., R. W. Masulis, and O. Norli. 2007. Security Offerings. In B. E. Eckbo (ed.), Handbook of Empirical Corporate Finance, pp. 233-373. San Diego: Elsevier.

Fenn, G. W., and N. Liang. 2001. Corporate payout policy and managerial stock incentives. Journal of Financial Economics 60:45-72.

Galai, D., and M. I. Schneller. 1978. Pricing of Warrants and the Value of the Firm. The Journal of Finance 33:1333-1342.

Ginglinger, E., and J. Hamon. 2007. Actual share repurchases, timing and liquidity. Journal of Banking \& Finance 31:915-938. 
Grullon, G., and R. Michaely. 2004. The Information Content of Share Repurchase Programs. The Journal of Finance 59:651-680.

Grullon, G., R. Michaely, and B. Swaminathan. 2002. Are Dividend Changes a Sign of Firm Maturity? The Journal of Business 75:387-424.

Ikenberry, D., J. Lakonishok, and T. Vermaelen. 1995. Market underreaction to open market share repurchases. Journal of Financial Economics 39:181-208.

Jolls, C. 1998. Stock Repurchases and Incentive Compensation. Working Paper 6467, National Bureau of Economic Research.

Kahle, K. M. 2002. When a buyback isn't a buyback: Open market repurchases and employee options. Journal of Financial Economics 63:235-261.

Rees, W. 1996. The impact of open market equity repurchases on UK equity prices. The European Journal of Finance 2:353-370.

Skinner, D. J. 2008. The evolving relation between earnings, dividends, and stock repurchases. Journal of Financial Economics 87:582-609.

Sonika, R., N. F. Carline, and M. B. Shackleton. 2014. The Option and Decision to Repurchase Stock. Financial Management 43:833-855.

Stephens, C. P., and M. S. Weisbach. 1998. Actual Share Reacquisitions in Open-Market Repurchase Programs. The Journal of Finance 53:313-333.

Vermaelen, T. 1981. Common stock repurchases and market signalling : An empirical study. Journal of Financial Economics 9:139-183.

Weisbenner, S. J. 2000. Corporate Share Repurchases in the 1990s: What Role Do Stock Options Play? AFA 2002 Atlanta Meetings; FEDS Working Paper No. 2000-29. Available at: http://dx.doi.org/10.2139/ssrn.234164. 
Table 1: Sample selection criteria

This table describes the selection criteria used to determine the sample data for the study, illustrating the breakdown of the unique number of firms used in the study. Identification of firms is done using data from Securities Data Company (SDC) database and subsequently filtered to arrive at a unique set of firms. This is done due to the multiplicity of announcements by each firm in SDC not captured by database. We then detail the composition of the sample data after merging with BoardEx to utilise information on stock option exercisability. Since the BoardEx data begins in 1999, all observations prior to the period identified through SDC are lost. Final sample comprises 119 firms with repurchase programs, of which 80 conduct actual repurchases.

\begin{tabular}{|c|c|}
\hline Description & Number of Firms/Days \\
\hline $\begin{array}{l}\text { Number of repurchase events identified by SDC to occur in the UK between } 1990 \text { and } \\
2010 \\
\text { Less: } \\
\text { - Events attributed to financial and utility firms }\end{array}$ & $\begin{array}{l}338 \\
302\end{array}$ \\
\hline - Duplicate entries of repurchase intentions to identify unique list of firms & $\begin{array}{c}62 \\
240\end{array}$ \\
\hline - Firm identifiers not available to match information on Datastream/Worldscope & $\begin{array}{c}36 \\
204\end{array}$ \\
\hline - Annual report information not available in Perfect Information & $\frac{8}{196}$ \\
\hline - Firms not matched with BoardEx & 77 \\
\hline Total number of firm identified in the sample period from 1999 to 2010 & 119 \\
\hline Subset of authority firms that repurchase during the period of 1999 to 2010 & 80 \\
\hline Number of repurchase days for the repurchasing firms during the period of 1999 to 2010 & 9,214 \\
\hline
\end{tabular}




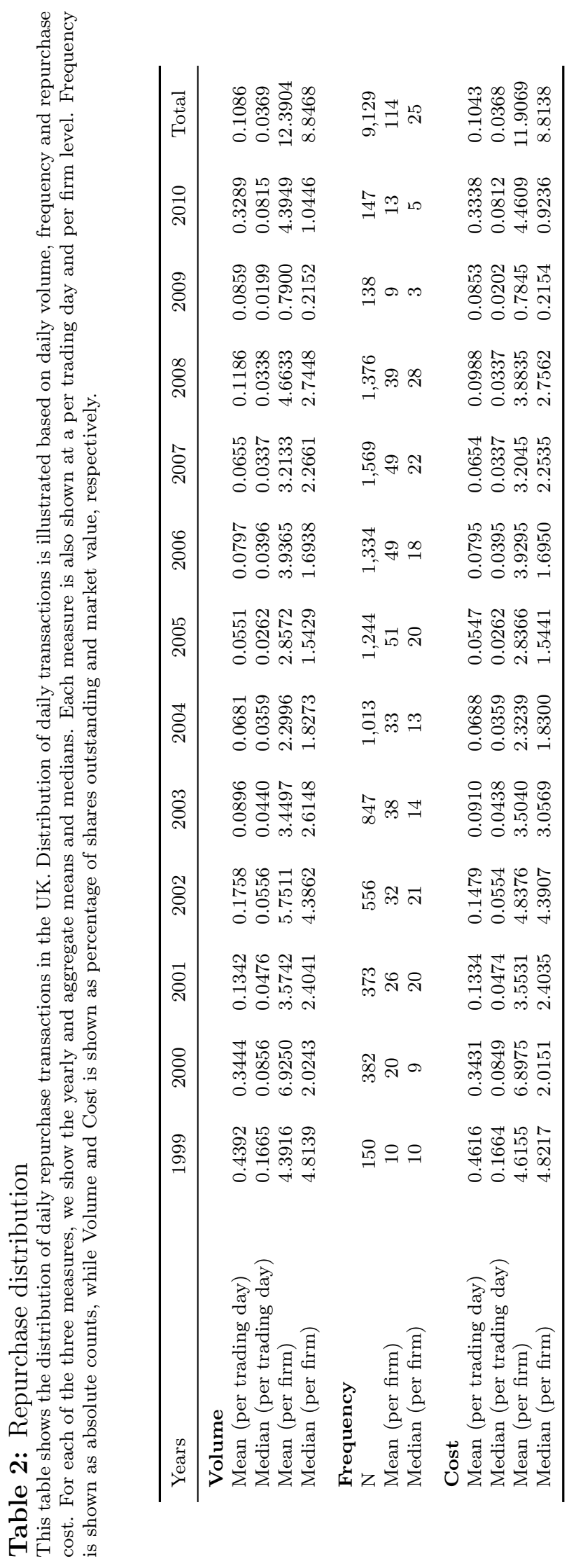


Table 3: Descriptive statistics

This table shows the descriptive statistics of sample firms used in the study. The table shows means, medians and standard deviation for all sample firms, differentiated between repurchasing and non-repurchasing. $p$-value for a twosided difference in means and Kruskal-Wallis rank test is also reported. Definition of how the variables are computed is provided in the appendix (Table A1).

\begin{tabular}{|c|c|c|c|c|c|c|c|c|}
\hline & \multicolumn{3}{|c|}{ Repurchasing firms $(\mathrm{N}=80)$} & \multicolumn{3}{|c|}{ Non-repurchasing firms $(\mathrm{N}=39)$} & \multicolumn{2}{|c|}{$p$-value of difference } \\
\hline & Mean & Median & $\mathrm{SD}$ & Mean & Median & SD & Mean & Median \\
\hline Treasury shares & 0.0252 & 0.0000 & 0.1270 & 0.0033 & 0.0000 & 0.0400 & 0.0000 & 0.0001 \\
\hline Size & 16,985 & 5,325 & 27,836 & 4,700 & 234.8 & 16,071 & 0.0000 & 0.0001 \\
\hline Market-to-book & 1.9500 & 1.6210 & 1.9780 & 1.7050 & 1.3380 & 2.4770 & 0.0000 & 0.0001 \\
\hline Leverage & 0.2000 & 0.1800 & 0.1670 & 0.1360 & 0.1040 & 0.1500 & 0.0000 & 0.0001 \\
\hline Cash & 0.1080 & 0.0660 & 0.1230 & 0.1310 & 0.0744 & 0.3720 & 0.0000 & 0.0002 \\
\hline Return on assets & 0.1480 & 0.1290 & 0.1320 & 0.1010 & 0.1100 & 0.1970 & 0.0000 & 0.0001 \\
\hline Return volatility & 0.2450 & 0.2140 & 0.1220 & 0.3200 & 0.2810 & 0.1770 & 0.0000 & 0.0001 \\
\hline Average spread & 1.8520 & 1.3440 & 4.1070 & 5.8460 & 2.6550 & 13.8800 & 0.0000 & 0.0001 \\
\hline Lagged return & 0.0075 & 0.0484 & 0.2340 & 0.0139 & 0.0503 & 0.3570 & 0.0129 & 0.0001 \\
\hline Dividend payout & 48.6400 & 52.0100 & 21.7000 & 39.7900 & 42.6600 & 28.6300 & 0.0000 & 0.0001 \\
\hline Total options & 0.0046 & 0.0016 & 0.0100 & 0.0107 & 0.0033 & 0.0181 & 0.0000 & 0.0000 \\
\hline Unexercisable, in-the-money options & 0.0004 & 0.0000 & 0.0014 & 0.0014 & 0.0000 & 0.0045 & 0.0000 & 0.0001 \\
\hline Unexercisable, out-of-the-money options & 0.0015 & 0.0001 & 0.0050 & 0.0024 & 0.0000 & 0.0069 & 0.0000 & 0.0001 \\
\hline Exercisable, in-the-money options & 0.0006 & 0.0000 & 0.0024 & 0.0023 & 0.0000 & 0.0065 & 0.0000 & 0.0001 \\
\hline Exercisable, out-of-the-money options & 0.0020 & 0.0004 & 0.0060 & 0.0042 & 0.0001 & 0.0111 & 0.0000 & 0.0001 \\
\hline
\end{tabular}


Table 4: Size of repurchase (volume and value) and option holdings

This table shows the dynamic panel estimates of sample firms used in the study. The dependent variable in Columns (1) and (2) is the daily percentage of shares repurchased (scaled by shares outstanding), while in columns (3) and (4) is the daily percentage of value repurchased (scaled by market value). Option holdings is aggregate options outstanding scaled by total shares outstanding. Unexercisable and exercisable options are segregations of aggregate options outstanding based on exercisable date for all outstanding option plans at a firm-level. Both variables are scaled by total shares outstanding. Other control variables are as described in the appendix (Table A1). *, ** and $* * *$ refer to a two-sided ttest representing 10\%, $5 \%$ and $1 \%$ statistical significance. Also shown are p-values from a Sargan test for overidentification of instruments, and the Arellano-Bond test for serial correlation using $\mathrm{AR}(1)$ and $\mathrm{AR}(2)$ tests.

\begin{tabular}{|c|c|c|c|c|}
\hline & \multicolumn{2}{|c|}{ Repurchase volume } & \multicolumn{2}{|c|}{ Repurchase value } \\
\hline & (1) & $(2)$ & $(3)$ & $(4)$ \\
\hline Total options & $\begin{array}{c}0.0038^{* * *} \\
(6.10)\end{array}$ & & $\begin{array}{c}0.0065^{* * *} \\
(6.01)\end{array}$ & \\
\hline Unexercisable, in-the-money options & & $\begin{array}{c}-0.0023 \\
(-1.26)\end{array}$ & & $\begin{array}{c}-0.0032^{*} \\
(-1.74)\end{array}$ \\
\hline Unexercisable, out-of-the-money options & & $\begin{array}{c}0.0078^{* * *} \\
(3.93)\end{array}$ & & $\begin{array}{c}0.0214^{* * *} \\
(9.38)\end{array}$ \\
\hline Exercisable, in-the-money options & & $\begin{array}{c}0.0027^{* * *} \\
(2.90)\end{array}$ & & $\begin{array}{c}0.0071^{* * *} * \\
(8.62)\end{array}$ \\
\hline Exercisable, out-of-the-money options & & $\begin{array}{c}0.0030^{* * *} \\
(7.48)\end{array}$ & & $\begin{array}{c}0.0043^{* * *} \\
(7.23)\end{array}$ \\
\hline Treasury shares & $\begin{array}{c}-0.0023^{* * *} \\
(-2.66)\end{array}$ & $\begin{array}{c}-0.0016^{* *} \\
(-1.98)\end{array}$ & $\begin{array}{c}-0.0045^{* * *} \\
(-4.50)\end{array}$ & $\begin{array}{c}-0.0016^{*} \\
(-1.93)\end{array}$ \\
\hline Size & $\begin{array}{c}0.0048^{* * *} \\
(5.59)\end{array}$ & $\begin{array}{c}0.0044^{* * *} \\
(5.06)\end{array}$ & $\begin{array}{c}0.0080^{* * *} \\
(7.77)\end{array}$ & $\begin{array}{c}0.0051^{* * *} \\
(4.01)\end{array}$ \\
\hline Market-to-book & $\begin{array}{c}-0.0028^{* * *} \\
(-24.63)\end{array}$ & $\begin{array}{c}-0.0022^{* * *} \\
(-22.43)\end{array}$ & $\begin{array}{c}-0.0031^{* * *} \\
(-22.36)\end{array}$ & $\begin{array}{c}-0.0025^{* * *} \\
(-21.05)\end{array}$ \\
\hline Leverage & $\begin{array}{c}0.0312^{* * *} \\
(6.20)\end{array}$ & $\begin{array}{c}0.0319 * * * \\
(6.08)\end{array}$ & $\begin{array}{c}0.0400^{* * *} \\
(6.04)\end{array}$ & $\begin{array}{c}0.0413^{* * *} \\
(6.12)\end{array}$ \\
\hline Cash & $\begin{array}{c}-0.0069^{* * *} \\
(-7.02)\end{array}$ & $\begin{array}{c}-0.0051^{* * *} \\
(-6.61)\end{array}$ & $\begin{array}{c}-0.0104^{* * *} \\
(-9.56)\end{array}$ & $\begin{array}{c}-0.0061^{* * *} \\
(-7.15)\end{array}$ \\
\hline Return on assets & $\begin{array}{c}0.0409 * * * \\
(9.17)\end{array}$ & $\begin{array}{c}0.0321^{* * *} \\
(9.07)\end{array}$ & $\begin{array}{c}0.0589 * * * \\
(11.88)\end{array}$ & $\begin{array}{c}0.0379^{* * *} \\
(9.62)\end{array}$ \\
\hline Return volatility & $\begin{array}{c}0.0413^{* * *} \\
(7.89)\end{array}$ & $\begin{array}{c}0.0430^{* * * *} \\
(7.83)\end{array}$ & $\begin{array}{c}0.0807^{* * *} \\
(15.37)\end{array}$ & $\begin{array}{c}0.0789^{* * *} \\
(13.87)\end{array}$ \\
\hline Average spread & $\begin{array}{c}-0.0004^{* * *} \\
(-4.57)\end{array}$ & $\begin{array}{c}-0.0004^{* * *} \\
(-5.00)\end{array}$ & $\begin{array}{c}-0.0007^{* * *} \\
(-6.67)\end{array}$ & $\begin{array}{c}-0.0007^{* * *} \\
(-6.56)\end{array}$ \\
\hline Lagged return & $\begin{array}{c}-0.0079^{* * *} \\
(-8.75)\end{array}$ & $\begin{array}{c}-0.0089^{* * *} \\
(-8.95)\end{array}$ & $\begin{array}{c}-0.0104^{* * *} \\
(-13.48)\end{array}$ & $\begin{array}{c}-0.0105^{* * *} \\
(-10.40)\end{array}$ \\
\hline Dividend payout & $\begin{array}{c}-0.0000^{* *} \\
(-2.45)\end{array}$ & $\begin{array}{c}-0.0000^{* * *} \\
(-3.03)\end{array}$ & $\begin{array}{c}0.0000 \\
(0.92)\end{array}$ & $\begin{array}{c}-0.0000 \\
(-0.19)\end{array}$ \\
\hline Constant & $\begin{array}{c}-0.0308^{* * *} \\
(-4.54)\end{array}$ & $\begin{array}{c}-0.0277^{* * *} \\
(-4.09)\end{array}$ & $\begin{array}{c}-0.0551^{* * *} \\
(-7.90)\end{array}$ & $\begin{array}{c}-0.0365^{* * *} \\
(-4.41)\end{array}$ \\
\hline Sargan $p$-value & 1.0000 & 1.0000 & 1.0000 & 1.0000 \\
\hline Arellano-Bond $\mathrm{AR}(1)$ test & 0.0000 & 0.0000 & 0.0014 & 0.0014 \\
\hline Arellano-Bond $\mathrm{AR}(2)$ test & 0.3638 & 0.3759 & 0.6154 & 0.5751 \\
\hline Year dummies & Yes & Yes & Yes & Yes \\
\hline $\mathrm{N}$ & 232,563 & 232,563 & 232,563 & 232,563 \\
\hline
\end{tabular}


Table 5: Size of repurchase (volume and value) and option holdings: Treasury

This table shows linear panel estimates of sample firms used in the study, adjusting for Treasury regulation. The dependent variable in Columns (1) and (2) is the daily percentage of shares repurchased (scaled by shares outstanding), while in columns (3) and (4) is the daily percentage of value repurchased (scaled by market value). Option holdings is aggregate options outstanding scaled by total shares outstanding. Unexercisable and exercisable options are segregations of aggregate options outstanding based on exercisable date for all outstanding option plans at a firm-level. Both variables are scaled by total shares outstanding. Other control variables are as described in the appendix (Table A1). *, ** and *** refer to a two-sided t-test representing $10 \%, 5 \%$ and $1 \%$ statistical significance. Also shown are p-values from a Sargan test for overidentification of instruments, and the Arellano-Bond test for serial correlation using AR(1) and AR(2) tests.

\begin{tabular}{|c|c|c|c|c|}
\hline & \multicolumn{2}{|c|}{ Repurchase volume } & \multicolumn{2}{|c|}{ Repurchase value } \\
\hline & $(1)$ & $(2)$ & $(3)$ & $(4)$ \\
\hline Treasury dummy & $\begin{array}{c}0.0005 \\
(0.93)\end{array}$ & $\begin{array}{c}0.0010 \\
(0.84)\end{array}$ & $\begin{array}{c}0.0027^{* * *} \\
(2.73)\end{array}$ & $\begin{array}{c}0.0029^{*} \\
(1.94)\end{array}$ \\
\hline Total options & $\begin{array}{c}0.0035^{* * *} \\
(5.54)\end{array}$ & & $\begin{array}{c}0.0062^{* * *} \\
(5.86)\end{array}$ & \\
\hline Treasury $*$ Total options & $\begin{array}{c}0.0004 \\
(1.08)\end{array}$ & & $\begin{array}{c}0.0003 \\
(0.40)\end{array}$ & \\
\hline Unexercisable, in-the-money options & & $\begin{array}{c}0.0003 \\
(0.40)\end{array}$ & & $\begin{array}{c}0.0111^{* * *} \\
(4.53)\end{array}$ \\
\hline Unexercisable, out-of-the-money options & & $\begin{array}{c}-0.0007 \\
(-0.30)\end{array}$ & & $\begin{array}{c}-0.0024 \\
(-0.85)\end{array}$ \\
\hline Exercisable, in-the-money options & & $\begin{array}{c}0.0067^{* * *} \\
(2.82)\end{array}$ & & $\begin{array}{c}0.0058^{* * *} \\
(2.91)\end{array}$ \\
\hline Exercisable, out-of-the-money options & & $\begin{array}{c}0.0070^{* * *} \\
(3.61)\end{array}$ & & $\begin{array}{c}0.0114^{* * *} \\
(4.01)\end{array}$ \\
\hline Treasury $*$ Unexercisable, in-the-money options & & $\begin{array}{c}-0.0024 \\
(-1.00)\end{array}$ & & $\begin{array}{c}-0.0137^{* * *} \\
(-3.54)\end{array}$ \\
\hline Treasury $*$ Unexercisable, out-of-the-money options & & $\begin{array}{c}0.0105^{* *} \\
(2.23)\end{array}$ & & $\begin{array}{c}0.0243^{* * *} \\
(3.92)\end{array}$ \\
\hline Treasury * Exercisable, in-the-money options & & $\begin{array}{c}-0.0046^{*} \\
(-1.87)\end{array}$ & & $\begin{array}{c}-0.0022 \\
(-1.00)\end{array}$ \\
\hline Treasury ${ }^{*}$ Exercisable, out-of-the-money options & & $\begin{array}{c}-0.0062^{* * *} \\
(-2.82)\end{array}$ & & $\begin{array}{c}-0.0115^{* * *} \\
(-3.84)\end{array}$ \\
\hline Treasury shares & $\begin{array}{c}-0.0023^{* * *} \\
(-2.66)\end{array}$ & $\begin{array}{c}-0.0022^{* * *} \\
(-2.79)\end{array}$ & $\begin{array}{c}-0.0047^{* * *} \\
(-4.84)\end{array}$ & $\begin{array}{c}-0.0034^{* * *} \\
(-3.78)\end{array}$ \\
\hline Size & $\begin{array}{c}0.0048^{* * *} \\
(5.61)\end{array}$ & $\begin{array}{c}0.0039 * * * \\
(4.64)\end{array}$ & $\begin{array}{c}0.0082^{* * *} \\
(8.26)\end{array}$ & $\begin{array}{c}0.0067^{* * *} \\
(6.93)\end{array}$ \\
\hline Market-to-book & $\begin{array}{c}-0.0027^{* * *} \\
(-24.71)\end{array}$ & $\begin{array}{c}-0.0022^{* * *} \\
(-21.18)\end{array}$ & $\begin{array}{c}-0.0031^{* * *} \\
(-22.64)\end{array}$ & $\begin{array}{c}-0.0026^{* * *} \\
(-21.12)\end{array}$ \\
\hline Leverage & $\begin{array}{c}0.0313^{* * *} \\
\quad(6.21)\end{array}$ & $\begin{array}{c}0.0321^{* * *} \\
(6.05)\end{array}$ & $\begin{array}{c}0.0404^{* * *} \\
(6.12)\end{array}$ & $\begin{array}{c}0.0481^{* * *} \\
(7.79)\end{array}$ \\
\hline Cash & $\begin{array}{c}-0.0068^{* * *} \\
(-7.05)\end{array}$ & $\begin{array}{c}-0.0062^{* * *} \\
(-7.77)\end{array}$ & $\begin{array}{c}-0.0102^{* * *} \\
(-9.74)\end{array}$ & $\begin{array}{c}-0.0074^{* * *} \\
(-7.99)\end{array}$ \\
\hline Return on assets & $\begin{array}{c}0.0406^{* * *} \\
\quad(9.24)\end{array}$ & $\begin{array}{c}0.0325^{* * *} \\
(8.84)\end{array}$ & $\begin{array}{c}0.0582^{* * *} \\
(12.22)\end{array}$ & $\begin{array}{c}0.0377^{* * * *} \\
(8.94)\end{array}$ \\
\hline Return volatility & $\begin{array}{c}0.0416^{* * *} \\
(7.88)\end{array}$ & $\begin{array}{c}0.0337^{* * *} \\
(7.90)\end{array}$ & $\begin{array}{c}0.0811^{* * *} \\
(14.81)\end{array}$ & $\begin{array}{c}0.0601^{* * *} \\
(10.77)\end{array}$ \\
\hline Average spread & $\begin{array}{c}-0.0004^{* * *} \\
(-4.57)\end{array}$ & $\begin{array}{c}-0.0005^{* * *} \\
(-4.65)\end{array}$ & $\begin{array}{c}-0.0007^{* * *} \\
(-6.55)\end{array}$ & $\begin{array}{c}-0.0008^{* * *} \\
(-6.63)\end{array}$ \\
\hline Lagged return & $\begin{array}{c}-0.0079^{* * *} \\
(-8.77)\end{array}$ & $\begin{array}{c}-0.0085^{* * *} \\
(-8.87)\end{array}$ & $\begin{array}{c}-0.0105^{* * *} \\
(-14.07)\end{array}$ & $\begin{array}{c}-0.0114^{* * *} \\
(-14.52)\end{array}$ \\
\hline Dividend payout & $\begin{array}{c}-0.0000^{* *} \\
(-2.51)\end{array}$ & $\begin{array}{c}-0.0000^{* *} \\
(-2.30)\end{array}$ & $\begin{array}{c}0.0000 \\
(0.70)\end{array}$ & $\begin{array}{c}-0.0000 \\
(-0.65)\end{array}$ \\
\hline Constant & $\begin{array}{c}-0.0309^{* * *} \\
(-4.57)\end{array}$ & $\begin{array}{c}-0.0234^{* * *} \\
(-3.88) \\
\end{array}$ & $\begin{array}{c}-0.0562^{* * *} \\
(-8.26) \\
\end{array}$ & $\begin{array}{c}-0.0338^{* * *} \\
(-4.64) \\
\end{array}$ \\
\hline Sargan $p$-value & 1.0000 & 1.0000 & 1.0000 & 1.0000 \\
\hline Arellano-Bond AR(1) test & 0.0000 & 0.0000 & 0.0000 & 0.0000 \\
\hline Arellano-Bond $\mathrm{AR}(2)$ test & 0.3636 & 0.3377 & 0.5435 & 0.6098 \\
\hline Year dummies & Yes & Yes & Yes & Yes \\
\hline $\mathrm{N}$ & 232,563 & 232,563 & 232,563 & 232,563 \\
\hline
\end{tabular}


Table 6: Frequency of repurchase and option holdings

This table shows the repurchase incidence (frequency) rate of sample firms used in the study. The dependent variable in all columns is a count of repurchases on a monthly (columns 1 and 2) and weekly (columns 3 and 4 ) basis. Estimates presented are incidence rates indicating a higher $(>1)$ or lower $(<1)$ probability of repurchase. Option holdings is aggregate options outstanding scaled by total shares outstanding. Unexercisable and exercisable options are segregations of aggregate options outstanding based on exercisable date for all outstanding option plans at a firm-level. Both variables are scaled by total shares outstanding. Other control variables are as described in the appendix (Table A1). *, ** and *** refer to a two-sided t-test representing $10 \%, 5 \%$ and $1 \%$ statistical significance.

\begin{tabular}{|c|c|c|c|c|}
\hline & \multicolumn{2}{|c|}{ Monthly } & \multicolumn{2}{|c|}{ Weekly } \\
\hline & $(1)$ & $(2)$ & $(3)$ & $(4)$ \\
\hline Total options & $\begin{array}{c}1.0736^{* *} \\
(2.06)\end{array}$ & & $\begin{array}{c}1.1383^{* * *} \\
(5.38)\end{array}$ & \\
\hline Unexercisable, in-the-money options & & $\begin{array}{c}0.5547^{* * *} \\
(-2.70)\end{array}$ & & $\begin{array}{c}0.6953^{* * *} \\
(-2.64)\end{array}$ \\
\hline Unexercisable, out-of-the-money options & & $\begin{array}{c}1.2642^{* * *} \\
(3.53)\end{array}$ & & $\begin{array}{c}1.2500^{* * *} \\
(4.67)\end{array}$ \\
\hline Exercisable, in-the-money options & & $\begin{array}{l}1.0570 \\
(0.47)\end{array}$ & & $\begin{array}{c}1.2357^{* *} \\
(2.50)\end{array}$ \\
\hline Exercisable, out-of-the-money options & & $\begin{array}{l}1.0185 \\
(0.37)\end{array}$ & & $\begin{array}{c}1.0733^{*} \\
(1.90)\end{array}$ \\
\hline Treasury shares & $\begin{array}{c}2.5815^{* * *} \\
(3.25)\end{array}$ & $\begin{array}{c}2.5795^{* * * *} \\
(3.24)\end{array}$ & $\begin{array}{c}1.8281^{* * *} \\
(3.63)\end{array}$ & $\begin{array}{c}1.8362^{* * *} \\
(3.66)\end{array}$ \\
\hline Size & $\begin{array}{l}1.0349 \\
(1.44)\end{array}$ & $\begin{array}{l}1.0265 \\
(1.09)\end{array}$ & $\begin{array}{c}1.0840^{* * *} \\
(4.50)\end{array}$ & $\begin{array}{c}1.0774^{* * *} \\
(4.13)\end{array}$ \\
\hline Market-to-book & $\begin{array}{l}1.0177 \\
(0.66)\end{array}$ & $\begin{array}{l}1.0213 \\
(0.80)\end{array}$ & $\begin{array}{c}1.0096 \\
(0.50)\end{array}$ & $\begin{array}{c}1.0120 \\
(0.62)\end{array}$ \\
\hline Leverage & $\begin{array}{c}0.6181^{* *} \\
(-2.04)\end{array}$ & $\begin{array}{c}0.6438^{*} \\
(-1.86)\end{array}$ & $\begin{array}{c}0.7334^{*} \\
(-1.95)\end{array}$ & $\begin{array}{c}0.7463 * \\
(-1.83)\end{array}$ \\
\hline Cash & $\begin{array}{c}1.0170 \\
(0.22)\end{array}$ & $\begin{array}{l}0.9912 \\
(-0.11)\end{array}$ & $\begin{array}{c}1.1775^{* * * *} \\
(2.80)\end{array}$ & $\begin{array}{c}1.1361^{* *} \\
(2.21)\end{array}$ \\
\hline Return on assets & $\begin{array}{c}2.2380^{* *} \\
(2.06)\end{array}$ & $\begin{array}{c}1.9963^{*} \\
(1.83)\end{array}$ & $\begin{array}{c}1.3964 \\
(1.21)\end{array}$ & $\begin{array}{l}1.3305 \\
(1.05)\end{array}$ \\
\hline Return volatility & $\begin{array}{c}0.0236^{* * *} \\
(-11.78)\end{array}$ & $\begin{array}{c}0.0275^{* * *} \\
(-11.20)\end{array}$ & $\begin{array}{c}0.0105^{* * *} \\
(-21.72)\end{array}$ & $\begin{array}{c}0.0115^{* * *} \\
(-21.10)\end{array}$ \\
\hline Average spread & $\begin{array}{l}0.9903 \\
(-1.64)\end{array}$ & $\begin{array}{c}0.9893^{*} \\
(-1.79)\end{array}$ & $\begin{array}{c}0.9877^{* *} \\
(-2.09)\end{array}$ & $\begin{array}{c}0.9869^{* *} \\
(-2.25)\end{array}$ \\
\hline Lagged return & $\begin{array}{c}0.4406^{* * *} \\
(-6.64)\end{array}$ & $\begin{array}{c}0.4378^{* * *} \\
(-6.68)\end{array}$ & $\begin{array}{c}0.3937^{* * *} * \\
(-11.67)\end{array}$ & $\begin{array}{c}0.3881^{* * *} \\
(-11.78)\end{array}$ \\
\hline Dividend payout & $\begin{array}{c}1.0037^{* *} \\
(2.40)\end{array}$ & $\begin{array}{c}1.0038^{* *} \\
(2.47)\end{array}$ & $\begin{array}{c}1.0021^{* *} \\
(2.10)\end{array}$ & $\begin{array}{c}1.0021^{* *} \\
(2.06)\end{array}$ \\
\hline Constant & $\begin{array}{c}0.1557^{* * *} \\
(-7.46)\end{array}$ & $\begin{array}{c}0.1632^{* * *} \\
(-7.23)\end{array}$ & $\begin{array}{c}0.1945^{* * *} \\
(-8.95)\end{array}$ & $\begin{array}{c}0.2044^{* * *} \\
(-8.63)\end{array}$ \\
\hline Log Likelihood & -6080 & -6070 & -14150 & -14140 \\
\hline$p$-value & 0.0000 & 0.0000 & 0.0000 & 0.0000 \\
\hline $\mathrm{N}$ & 11,014 & 11,014 & 47,858 & 47,858 \\
\hline
\end{tabular}


Table 7: Frequency of repurchase and option holdings: Treasury

This table shows the repurchase incidence (frequency) rate of sample firms used in the study, adjusting for Treasury regulation. The dependent variable in all columns is a count of repurchases on a monthly (columns 1 and 2) and weekly (columns 3 and 4 ) basis. Estimates presented are incidence rates indicating a higher $(>1)$ or lower $(<1)$ probability of repurchase. Option holdings is aggregate options outstanding scaled by total shares outstanding. Unexercisable and exercisable options are segregations of aggregate options outstanding based on exercisable date for all outstanding option plans at a firm-level. Both variables are scaled by total shares outstanding. Other control variables are as described in the appendix (Table A1). ${ }^{*},{ }^{* *}$ and ${ }^{* * *}$ refer to a two-sided t-test representing $10 \%, 5 \%$ and $1 \%$ statistical significance.

\begin{tabular}{|c|c|c|c|c|}
\hline & \multicolumn{2}{|c|}{ Monthly } & \multicolumn{2}{|c|}{ Weekly } \\
\hline & $(1)$ & $(2)$ & $(3)$ & $(4)$ \\
\hline Treasury dummy & $\begin{array}{l}0.9891 \\
(-0.14)\end{array}$ & $\begin{array}{l}0.9547 \\
(-0.56)\end{array}$ & $\begin{array}{c}1.1015^{*} \\
(1.88)\end{array}$ & $\begin{array}{l}1.0224 \\
(0.41)\end{array}$ \\
\hline Total options & $\begin{array}{l}1.0775 \\
(1.36)\end{array}$ & & $\begin{array}{c}1.2502^{* * *} \\
(5.44)\end{array}$ & \\
\hline Treasury $*$ Total options & $\begin{array}{l}0.9954 \\
(-0.08)\end{array}$ & & $\begin{array}{c}0.8897^{* * *} \\
(-2.79)\end{array}$ & \\
\hline Unexercisable, in-the-money options & & $\begin{array}{l}0.6456 \\
(-1.48)\end{array}$ & & $\begin{array}{l}0.7175 \\
(-1.48)\end{array}$ \\
\hline Unexercisable, out-of-the-money options & & $\begin{array}{c}0.6446^{*} \\
(-1.78)\end{array}$ & & $\begin{array}{c}0.3740^{* * *} \\
(-4.20)\end{array}$ \\
\hline Exercisable, in-the-money options & & $\begin{array}{l}0.7539 \\
(-1.08)\end{array}$ & & $\begin{array}{l}0.9452 \\
(-0.30)\end{array}$ \\
\hline Exercisable, out-of-the-money options & & $\begin{array}{c}1.3377^{* * *} \\
(4.02)\end{array}$ & & $\begin{array}{c}1.6455^{* * *} \\
(9.61)\end{array}$ \\
\hline Treasury ${ }^{*}$ Unexercisable, in-the-money options & & $\begin{array}{l}0.7760 \\
(-0.58)\end{array}$ & & $\begin{array}{c}1.0854 \\
(0.29)\end{array}$ \\
\hline Treasury ${ }^{*}$ Unexercisable, out-of-the-money options & & $\begin{array}{c}2.1234^{* * *} \\
(2.99)\end{array}$ & & $\begin{array}{c}3.7620^{* * *} \\
(5.58)\end{array}$ \\
\hline Treasury * Exercisable, in-the-money options & & $\begin{array}{l}1.4472 \\
(1.32)\end{array}$ & & $\begin{array}{l}1.2242 \\
(1.03)\end{array}$ \\
\hline Treasury * Exercisable, out-of-the-money options & & $\begin{array}{c}0.6826^{* * *} \\
(-4.33)\end{array}$ & & $\begin{array}{c}0.5376^{* * *} \\
(-9.61)\end{array}$ \\
\hline Treasury shares & $\begin{array}{c}2.5937^{* * *} \\
(3.24)\end{array}$ & $\begin{array}{c}2.6076^{* * *} \\
(3.26)\end{array}$ & $\begin{array}{c}1.7658^{* * *} \\
(3.40)\end{array}$ & $\begin{array}{c}1.7958^{* * *} \\
(3.51)\end{array}$ \\
\hline Size & $\begin{array}{l}1.0350 \\
(1.44)\end{array}$ & $\begin{array}{l}1.0271 \\
(1.11)\end{array}$ & $\begin{array}{c}1.0873^{* * *} \\
(4.66)\end{array}$ & $\begin{array}{c}1.0831^{* * *} \\
(4.42)\end{array}$ \\
\hline Market-to-book & $\begin{array}{l}1.0178 \\
(0.66)\end{array}$ & $\begin{array}{l}1.0343 \\
(1.25)\end{array}$ & $\begin{array}{l}1.0131 \\
(0.68)\end{array}$ & $\begin{array}{l}1.0207 \\
(1.04)\end{array}$ \\
\hline Leverage & $\begin{array}{c}0.6197^{* *} \\
(-2.02)\end{array}$ & $\begin{array}{c}0.6526^{*} \\
(-1.80)\end{array}$ & $\begin{array}{c}0.7155^{* *} \\
(-2.09)\end{array}$ & $\begin{array}{c}0.7451^{*} \\
(-1.83)\end{array}$ \\
\hline Cash & $\begin{array}{l}1.0151 \\
(0.19)\end{array}$ & $\begin{array}{l}1.0556 \\
(0.60)\end{array}$ & $\begin{array}{c}1.1479^{* *} \\
(2.36)\end{array}$ & $\begin{array}{c}1.3186^{* * *} \\
(3.76)\end{array}$ \\
\hline Return on assets & $\begin{array}{c}2.2532^{* *} \\
(2.06)\end{array}$ & $\begin{array}{l}1.7573 \\
(1.47)\end{array}$ & $\begin{array}{l}1.4549 \\
(1.35)\end{array}$ & $\begin{array}{c}1.2622 \\
(0.86)\end{array}$ \\
\hline Return volatility & $\begin{array}{c}0.0232^{* * *} \\
(-11.43)\end{array}$ & $\begin{array}{c}0.0257^{* * *} \\
(-11.02)\end{array}$ & $\begin{array}{c}0.0115^{* * *} \\
(-20.28)\end{array}$ & $\begin{array}{c}0.0108^{* * *} \\
(-20.26)\end{array}$ \\
\hline Average spread & $\begin{array}{l}0.9901 \\
(-1.64)\end{array}$ & $\begin{array}{c}0.9899 * \\
(-1.67)\end{array}$ & $\begin{array}{c}0.9892^{*} \\
(-1.79)\end{array}$ & $\begin{array}{l}0.9902 \\
(-1.63)\end{array}$ \\
\hline Lagged return & $\begin{array}{c}0.4408^{* * *} \\
(-6.63)\end{array}$ & $\begin{array}{c}0.4423 * * * \\
(-6.59)\end{array}$ & $\begin{array}{c}0.3924 * * * \\
(-11.71)\end{array}$ & $\begin{array}{c}0.3950 * * * \\
(-11.59)\end{array}$ \\
\hline Dividend payout & $\begin{array}{c}1.0036^{* *} \\
(2.36)\end{array}$ & $\begin{array}{c}1.0037^{* *} \\
(2.39)\end{array}$ & $\begin{array}{c}1.0024^{* *} \\
(2.32)\end{array}$ & $\begin{array}{c}1.0020^{* *} \\
(1.98)\end{array}$ \\
\hline Constant & $\begin{array}{c}0.1574^{* * *} \\
(-6.97)\end{array}$ & $\begin{array}{c}0.1714^{* * * *} \\
(-6.57)\end{array}$ & $\begin{array}{c}0.1692^{* * *} \\
(-9.13)\end{array}$ & $\begin{array}{c}0.1943^{* * *} \\
(-8.27)\end{array}$ \\
\hline Log Likelihood & -6090 & -6070 & -14100 & -14000 \\
\hline$p$-value & 0.0000 & 0.0000 & 0.0000 & 0.0000 \\
\hline $\mathrm{N}$ & 11014 & 11014 & 47858 & 47858 \\
\hline
\end{tabular}




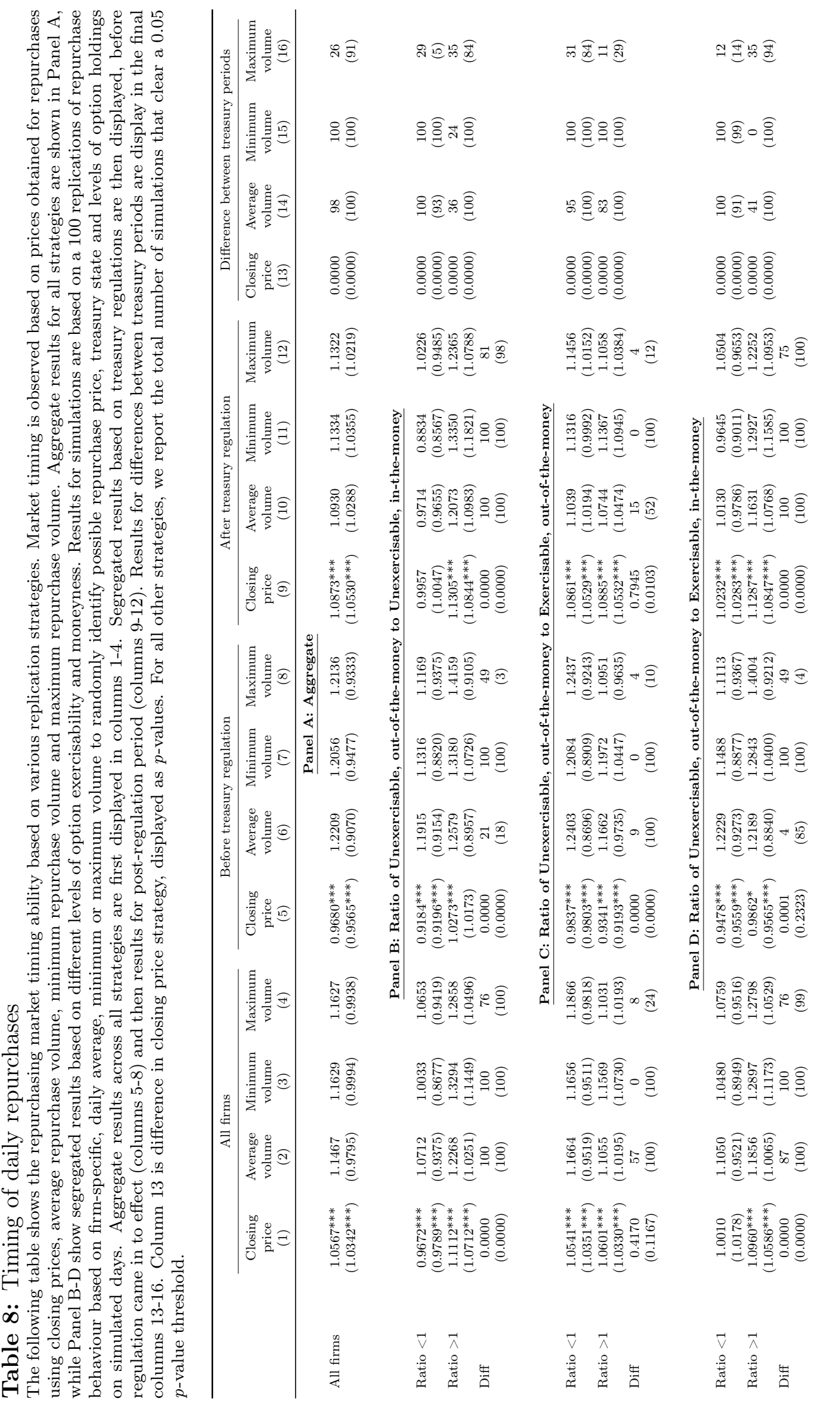


Table A1: Variable definitions

This table presents the description of variables used in the study. The computation of the explanatory variables is provided as the description, along with their respective Datastream/ Worldscope codes (in parentheses), where applicable. All variables have been winsorised at 1 percent, and computed on a 12-month rolling basis, unless otherwise specified.

\begin{tabular}{|c|c|}
\hline Variables & Description \\
\hline Total options & $\begin{array}{l}\text { Based on data from BoardEx, it represents the total (exercisable and } \\
\text { unexercisable) options outstanding, scaled by total shares outstanding. }\end{array}$ \\
\hline Unexercisable options & $\begin{array}{l}\text { A subset of option holdings, representing options that are unvested } \\
\text { (unexercisable). Actual vesting dates are used to determine the unex- } \\
\text { ercisable state and their respective proportions. }\end{array}$ \\
\hline Exercisable options & $\begin{array}{l}\text { A subset of option holdings, representing options that are vested (ex- } \\
\text { ercisable). Actual vesting dates are used to determine the exercisable } \\
\text { state and their respective proportions. }\end{array}$ \\
\hline In-the-money options & $\begin{array}{l}\text { A subset of option holdings, representing options that are above option } \\
\text { exercise price. Daily share prices are scaled by option strike prices to } \\
\text { determine a weighted average price-to-strike ratio. Options with a ratio } \\
\text { greater than } 1 \text { are considered in-the-money. }\end{array}$ \\
\hline Out-of-money options & $\begin{array}{l}\text { A subset of option holdings, representing options that are below option } \\
\text { exercise price. Daily share prices are scaled by option strike prices to } \\
\text { determine a weighted average price-to-strike ratio. Options with a ratio } \\
\text { less than } 1 \text { are considered out-of-money. }\end{array}$ \\
\hline Treasury dummy & $\begin{array}{l}\text { Dummy variable takes the value of } 1 \text { if repurchase takes place after } 1 \text { st } \\
\text { December } 2003 \text {, and } 0 \text { for all prior buybacks. }\end{array}$ \\
\hline Treasury shares & $\begin{array}{l}\text { Quarter-lagged ratio of total treasury shares scaled by shares outstand- } \\
\text { ing. }\end{array}$ \\
\hline Size & $\begin{array}{l}\text { Log-normalised value of total firm equity determined daily through the } \\
\text { product of daily closing price (UP) and number of shares outstanding } \\
\text { (NOSH). }\end{array}$ \\
\hline Market-to-book & $\begin{array}{l}\text { Market-to-book ratio measured as market value (book value of debt: } \\
\text { WC02999-WC03501, plus market value of equity: UP } * \text { NOSH) scaled } \\
\text { by book value of assets (WC02999) in } 2011 \text { terms. }\end{array}$ \\
\hline Leverage & $\begin{array}{l}\text { Net leverage computed as net debt (total liabilities net of cash hold- } \\
\text { ings: WC03251-WC02001) scaled by net assets (total assets net of cash } \\
\text { holdings: WC02999-WC02001). }\end{array}$ \\
\hline Cash & $\begin{array}{l}\text { Cash component computed as cash and cash equivalents (WC02001) } \\
\text { scaled by total assets (WC02999). }\end{array}$ \\
\hline Return on assets & $\begin{array}{l}\text { Return on assets determined as earnings before interest and tax but } \\
\text { after depreciation (WC18198) scaled by total assets (WC02999). }\end{array}$ \\
\hline Return volatility & $\begin{array}{l}\text { Daily computation of a 1-year lagged standard deviation of a security's } \\
\text { return index (RI), incorporating all distributions. }\end{array}$ \\
\hline Average spread & $\begin{array}{l}\text { Daily computation of average } 3 \text {-month lagged spread between ask (PA) } \\
\text { and bid price }(\mathrm{PB}) \text {. }\end{array}$ \\
\hline Lagged return & $\begin{array}{l}\text { Log-normalised, 6-month rolling returns of a security's return index } \\
\text { (RI), incorporating all distributions. }\end{array}$ \\
\hline Dividend payout & $\begin{array}{l}\text { Ratio of total dividends per share paid in a trailing } 12 \text {-month period } \\
\text { scaled by earnings per share (WC09504). }\end{array}$ \\
\hline
\end{tabular}

